Article

\title{
Solution-Based Synthesis and Characterization of $\mathrm{Cu}_{2} \mathrm{ZnSnS}_{4}$ (CZTS) Thin Films
}

\author{
Ubaidah Syafiq ${ }^{1,2}$, Narges Ataollahi ${ }^{1}$ (), Rosa Di Maggio ${ }^{1}$ and Paolo Scardi ${ }^{1, *(1)}$ \\ 1 Department of Civil, Environmental and Mechanical Engineering, University of Trento, Via Mesiano, 77, \\ 38123 Trento, Italy; muhammad.mustaffa@unitn.it (U.S.); narges.ataollahi@unitn.it (N.A.); \\ rosa.dimaggio@unitn.it (R.D.M.) \\ 2 Solar Energy Research Institute, National University of Malaysia (SERI-UKM), Bangi 43600, \\ Selangor, Malaysia \\ * Correspondence: paolo.scardi@unitn.it; Tel.: +39-0461282417; Fax: +39-0461281999
}

Academic Editors: Igor Djerdj and Jasminka Popović

Received: 2 September 2019; Accepted: 20 September 2019; Published: 23 September 2019

\begin{abstract}
Cu}_{2} \mathrm{ZnSnS}_{4}$ (CZTS) ink was synthesized from metal chloride precursors, sulfur, and oleylamine (OLA), as a ligand by a simple and low-cost hot-injection method. Thin films of CZTS were then prepared by spin coating, followed by thermal annealing. The effects of the fabrication parameters, such as ink concentration, spinning rate, and thermal treatment temperatures on the morphology and structural, optical, and electrical properties of the films were investigated. As expected, very thin films, for which the level of transmittance and band-gap values increase, can be obtained either by reducing the concentration of the inks or by increasing the rate of spinning. Moreover, the thermal treatment affects the phase formation and crystallinity of the film, as well as the electrical conductivity, which decreases at a higher temperature.
\end{abstract}

Keywords: $\mathrm{Cu}_{2} \mathrm{ZnSnS}_{4}$; thin film; spin coating; morphology; optical properties; phase change; electrical properties

\section{Introduction}

Kesterite, or CZTS, is a quaternary sulfide containing copper $(\mathrm{Cu})$, zinc $(\mathrm{Zn})$, tin $(\mathrm{Sn})$, and sulfur (S) with the formula $(\mathrm{I})_{2}(\mathrm{II})(\mathrm{III})(\mathrm{IV})_{4}$. As a semiconducting compound, kesterite has p-type conductivity [1] and can withstand temperature up to $800{ }^{\circ} \mathrm{C}$ [2]. It was initially considered as an adsorbing material in thin-film solar cells to replace $\mathrm{Cu}(\mathrm{In}, \mathrm{Ga}) \mathrm{Se}_{2}$ (CIGS), whose elements are expensive and scarcely available. Indeed, CZTS exhibits good light-harvesting performance, with an optimal band gap energy around $1.5-1.6 \mathrm{eV}[3,4]$, given by conduction and valence bands around -3.8 and $-5.2 \mathrm{eV}$, respectively $[5,6]$. The external quantum efficiency (EQE) for CZTS solar cells shows that the light-harvesting process starts from about $400 \mathrm{~nm}$ up to more than $800 \mathrm{~nm}$ [7] radiation wavelength.

Nowadays, fabrication of films from CZTS suspension through the ink-based approach has attracted considerable research interest as a simple, economic, and industrially scalable route, compared to the more expensive vacuum deposition methods. This method allows better material utilization with high throughput. Moreover, an ink-based approach lets simple deposition methods, such as spin coating, dip coating, spray coating, screen printing and ink-jet printing, be used [8-10]. Inks were prepared by solvo-thermal methodology, one of the simplest and fastest ways to synthesize high-quality CZTS nanoparticles on the gram scale, which involves the injection of a sulfur solution into a hot mixture of metal precursors dissolved in a solvent with a high boiling point [11]. In this regard, and despite the progresses in the production process, a fine control of the composition, shape, and size of CZTS nanoparticles requires complex metal sources, solvents, and ligands. Several studies demonstrated that solvents can affect the final shape of CZTS nanoparticles $[12,13]$, whereas the sulfur 
source and reaction temperature can affect the crystal structure [14]. Actually, a simple approach based on metal chlorides, sulfur powder and oleylamine (OLA), playing a double role of solvent and complexing agent, has been already proposed [4,15] to produce quaternary CZTS nanoparticles on the gram scale. A similar method has been successfully employed for producing CZTS nanoparticles for solar cell applications, with a device efficiency up to $10.3 \%$ [16].

Where the electrical properties of binary and ternary semiconductors have been studied for years [17-19], those of CZTS have been investigated more recently [20,21], especially taking into account their temperature dependence. In general, the electrical conductivity of CZTS films is due to Mott variable-range hopping and nearest neighbor hopping mechanisms below $-125{ }^{\circ} \mathrm{C}$. Above that temperature, the conductivity increases because of either thermionic emission of carriers over grain boundary barriers or the release of carriers from defect states [22]. In summary, two distinct modes of electronic transport are observed: hopping conduction (less than $-125^{\circ} \mathrm{C}$ ) and thermally activated conductivity (greater than $-125^{\circ} \mathrm{C}$ ). For ink-based CZTS thin films, it is reported that an increase in thermal treatment (TT) temperature increases the conductivity of the film, but evidence on this important aspect of the production process is still limited [21].

So far, properties of micrometric and sub-micrometric $(>0.5 \mu \mathrm{m})$ CZTS thin films fabricated using several different methods have been extensively studied [7,23-26] with the purpose of being the absorber layer in solar cell. There are also studies on CZTS thin films with $<0.5 \mu \mathrm{m}$ thickness, in which they are used as a transport layer in a perovskite solar cell [27-29]. However, their focus is on the application of the thin film in the solar cell, with limited information on properties. Thus, this study focuses on the influence of deposition parameters and thermal treatment on the morphology and structural, optical, and electrical properties of CZTS thin film synthesized using a hot-injection method, which has not, to the best of our knowledge, been reported in the literature. The main novelty of this study is the effect of thermal treatment on the crystal structure, which further affects other properties of the films at $<0.5 \mu \mathrm{m}$ thickness. The results of this study can provide some insights on the versatility of CZTS, not just as a traditional absorber layer, but as transport layer.

\section{Results and Discussion}

\subsection{CZTS Ink Concentration and Spin Rate}

The first parameter studied was ink concentration. Figure 1a,b shows the images from optical microscopy of the CZTS thin film with 0.5 and $0.2 \mathrm{~g} / \mathrm{mL}$ of CZTS nanoparticles in toluene, respectively; the lower the concentration, the lower the number of surface irregularities. The increase of CZTS nanoparticles per unit volume increased the possibility of agglomeration, which reduced the surface energy [30,31]. On the contrary, CZTS nanoparticles were better dispersed in a more diluted solution, thus providing a smooth and continuous layer of CZTS.

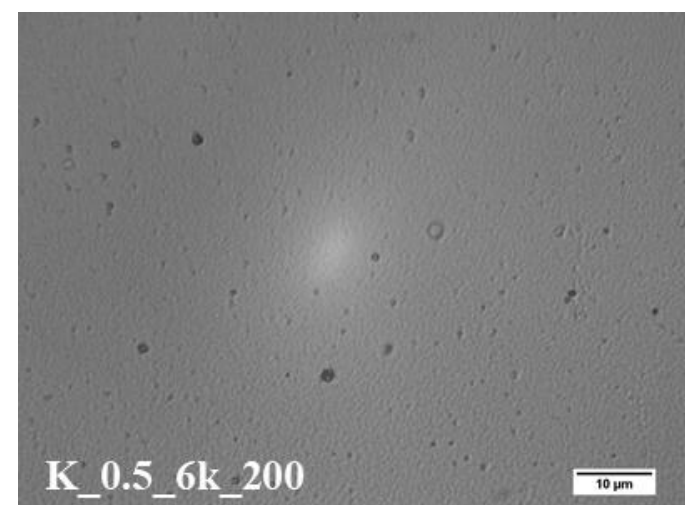

(a)

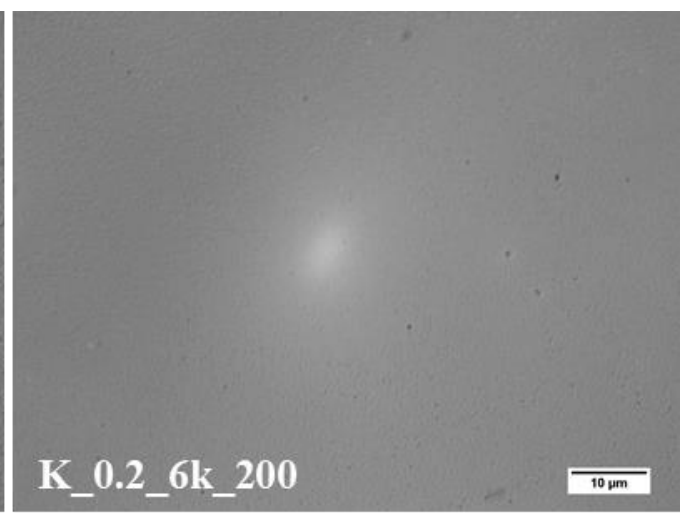

(b)

Figure 1. Cont. 


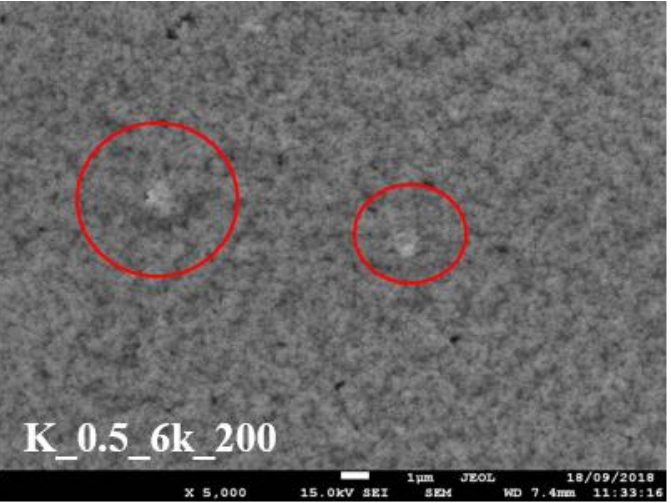

(c)

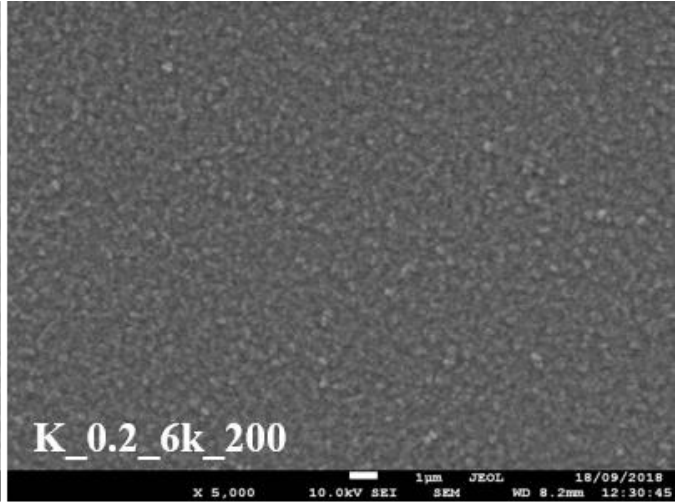

(d)

Figure 1. Surface of the $\mathrm{Cu}_{2} \mathrm{ZnSnS}_{4}$ (CZTS) thin film: (a,b) optical microscopy and (c,d) scanning electron microscopy (SEM) prepared by using ink with concentrations of nanoparticles at 0.5 and $0.2 \mathrm{~g} / \mathrm{mL}$, respectively.

Figure 1c,d shows the corresponding SEM pictures of the surface morphology of CZTS thin films with different ink concentrations deposited on fluorinated tin oxide (FTO) glass. In general, the obtained thin films consisted of continuous layers of CZTS nanoparticles that homogenously covered the entire surface of FTO glass. However, some agglomeration, highlighted by red circles, was visible on CZTS thin films prepared with $0.5 \mathrm{~g} / \mathrm{mL}$ ink. After deposition, the higher packing density forced some nanoparticles to form agglomerates, resulting in a lower surface energy [32].

SEM observations of the cross-section of the thin films with different ink concentrations (Figure 2) allowed us to evaluate the thickness of the thin films. The average thickness observed for CZTS thin films with 0.5 and $0.2 \mathrm{~g} / \mathrm{mL}$ concentrations were $\sim 336$ and $\sim 135 \mathrm{~nm}$, respectively. As expected, the higher the ink concentration, the thicker the thin films were.

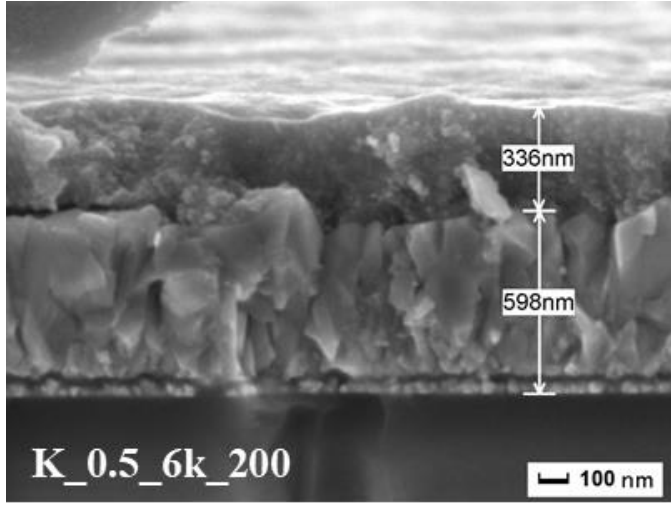

(a)

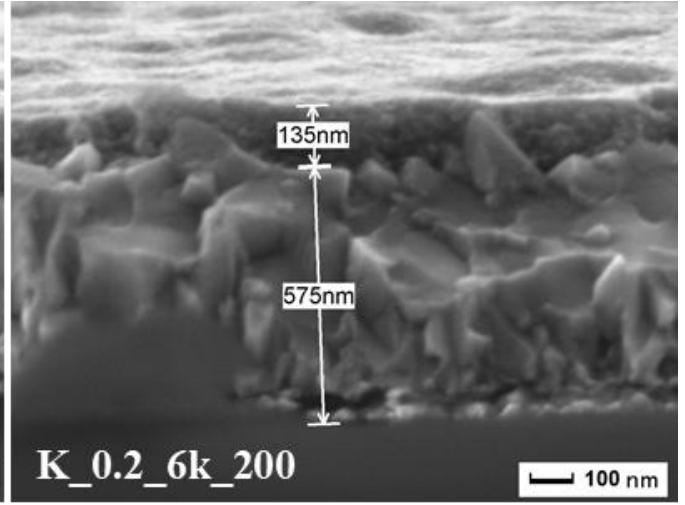

(b)

Figure 2. Cross-section of the CZTS thin film on fluorinated tin oxide (FTO) glass by SEM, prepared with ink having concentrations of (a) $0.5 \mathrm{~g} / \mathrm{mL}$ and (b) $0.2 \mathrm{~g} / \mathrm{mL}$, respectively.

Figure 3a shows the ultraviolet-visible (UV-vis) spectroscopy results with different ink concentrations. The CZTS thin film with $0.2 \mathrm{~g} / \mathrm{mL}$ ink has a higher transmittance level compared to $0.5 \mathrm{~g} / \mathrm{mL}$ ink. UV-vis spectroscopy (Figure $3 \mathrm{~b}$ ) of the CZTS thin film deposited on the FTO glass shows that with an increasing spin rate, the transmittance correspondingly increases. According to Beer-Lambert's law, a decrease in thickness of a material will decrease its absorption, thus causing an increase in transmittance [33,34]. This result confirms that the lower the ink concentration and the higher the spin rate are, the thinner the CZTS film will be. 
Tauc's plot of CZTS thin films with different ink concentrations are shown in the insert of Figure 3a. The band gaps for CZTS thin films were $\sim 1.45$ and $\sim 1.68 \mathrm{eV}$, for inks having nanoparticle concentrations of 0.5 and $0.2 \mathrm{~g} / \mathrm{mL}$, respectively.

Although the band gaps obtained were still in accordance with the band gap range of CZTS reported in the literature $[3,5,6]$, the decrease in band gap with an increasing concentration can be related to the greater thickness of CZTS thin film deposited. There is a possibility of structural defects in the film, which could give rise to localized states near the conduction band. In the case of thick films, these localized states may as well merge with the conduction band, resulting in a reduction of the bandgap [35].

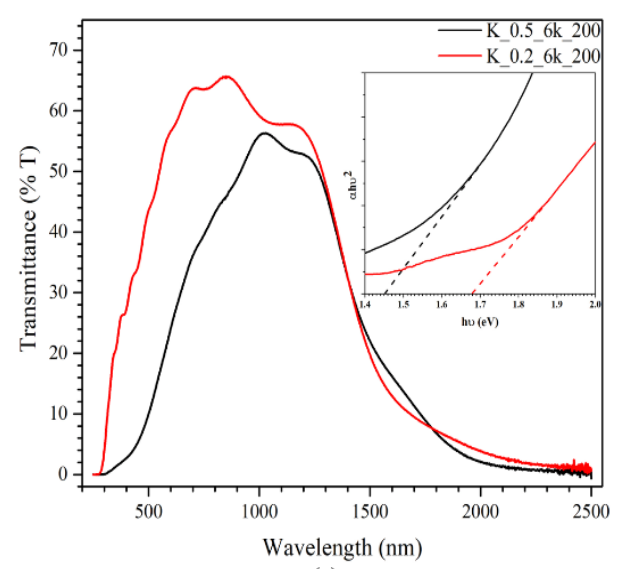

(a)

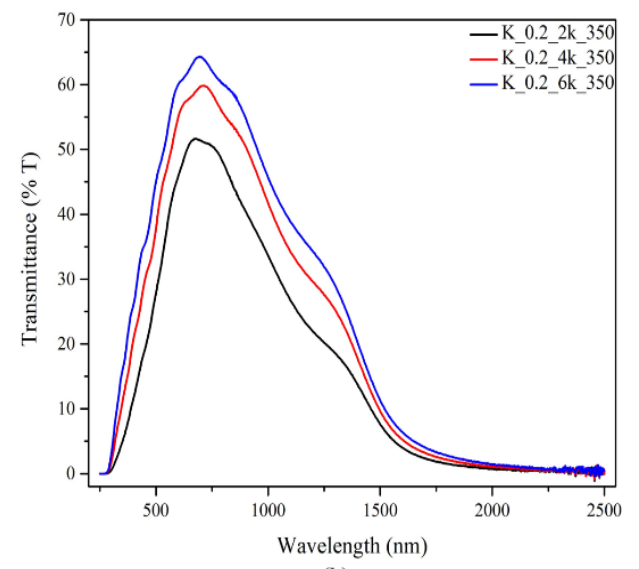

(b)

Figure 3. UV-vis spectroscopy of the CZTS thin film (a) prepared by ink having concentrations of $0.5 \mathrm{~g} / \mathrm{mL}$ (red line) and $0.2 \mathrm{~g} / \mathrm{mL}$ (black line), the insert is Tauc's plot of corresponding CZTS thin film, and (b) at different spin rates: black line, $2000 \mathrm{rpm}$; red line, $4000 \mathrm{rpm}$; and blue line, $6000 \mathrm{rpm}$.

\subsection{TT Temperature}

The effect of TT temperature on CZTS thin film samples, obtained from $0.2 \mathrm{~g} / \mathrm{mL}$ ink spread at a $6000 \mathrm{rpm}$ spin rate, was studied in terms of its surface morphology, grain growth, optical behavior, and electrical properties. Figure 4 shows the micrograph of the surface of CZTS thin films treated at temperatures from 150 to $350{ }^{\circ} \mathrm{C}$. The treatments in the range $240-280{ }^{\circ} \mathrm{C}$ seemed to induce cracks in samples, probably because of excessive drying and the shrinkage rate [36,37]. In fact, the samples treated at 150 and $200{ }^{\circ} \mathrm{C}$ appeared smooth and continuous. Also, the thin films treated at 300, 320, and $350^{\circ} \mathrm{C}$ did not show cracks because, at those temperatures, the CZTS grain growth [38] and phase changes compensated the shrinkage and avoided crack formation. 


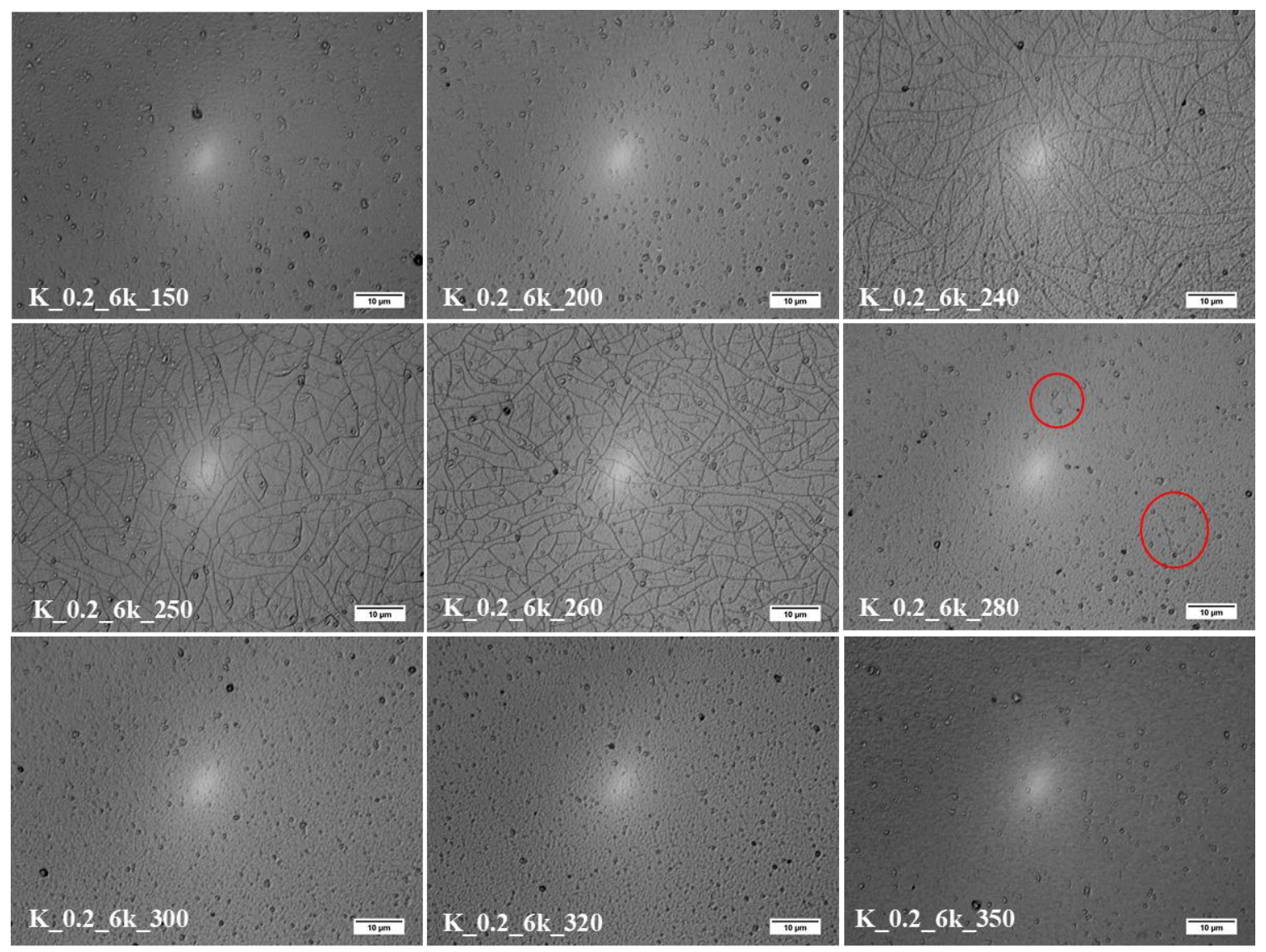

Figure 4. Morphology of the CZTS thin film surface by optical microscope at different TT temperatures indicated on each micrograph.

In Figure 5, the X-ray diffraction (XRD) spectra of the samples treated at 200, 350, and $500{ }^{\circ} \mathrm{C}$ are shown, demonstrating that different CZTS phases formed. At TT $200{ }^{\circ} \mathrm{C}$, a mix of cubic (distinctive peaks at $2 \theta=\sim 33.2^{\circ}, \sim 38.5^{\circ}, \sim 55.7^{\circ}$, and $\sim 66.3^{\circ}$ ) and hexagonal, also known as wurtzite (at $2 \theta=\sim 31.4^{\circ}$, $\sim 35.3^{\circ}$ ), CZTS phases formed [39]. At TT $350^{\circ} \mathrm{C}$, only cubic CZTS phase formed [40]. At TT $500{ }^{\circ} \mathrm{C}$, a tetragonal (distinctive peaks at $2 \theta=\sim 18.9^{\circ}, \sim 21.3^{\circ}$, and $\sim 38.5^{\circ}$ ) $[15,41]$ peak formed, and also a secondary phase, tin (II) sulfide (SnS), formed having main peaks at $2 \theta=\sim 25.8^{\circ}, \sim 30.4^{\circ}, \sim 31.9^{\circ}, \sim 35.6^{\circ}$, $\sim 36.8^{\circ}, \sim 37.2^{\circ}$, and $\sim 45.7^{\circ}$. It was demonstrated [40] that when the nanocrystals of CZTS are very small, they can be cubic or hexagonal, and with an increasing size, one observes cubic only, which evolve to the thermodynamically stable tetragonal form when crystals are big enough.

The crystallization process, and especially the grain growth, as demonstrated by the sharpness of peaks, was strongly promoted at $500^{\circ} \mathrm{C}$, while the formation of a secondary phase (SnS) might be due to unbalanced stoichiometry [42]. 


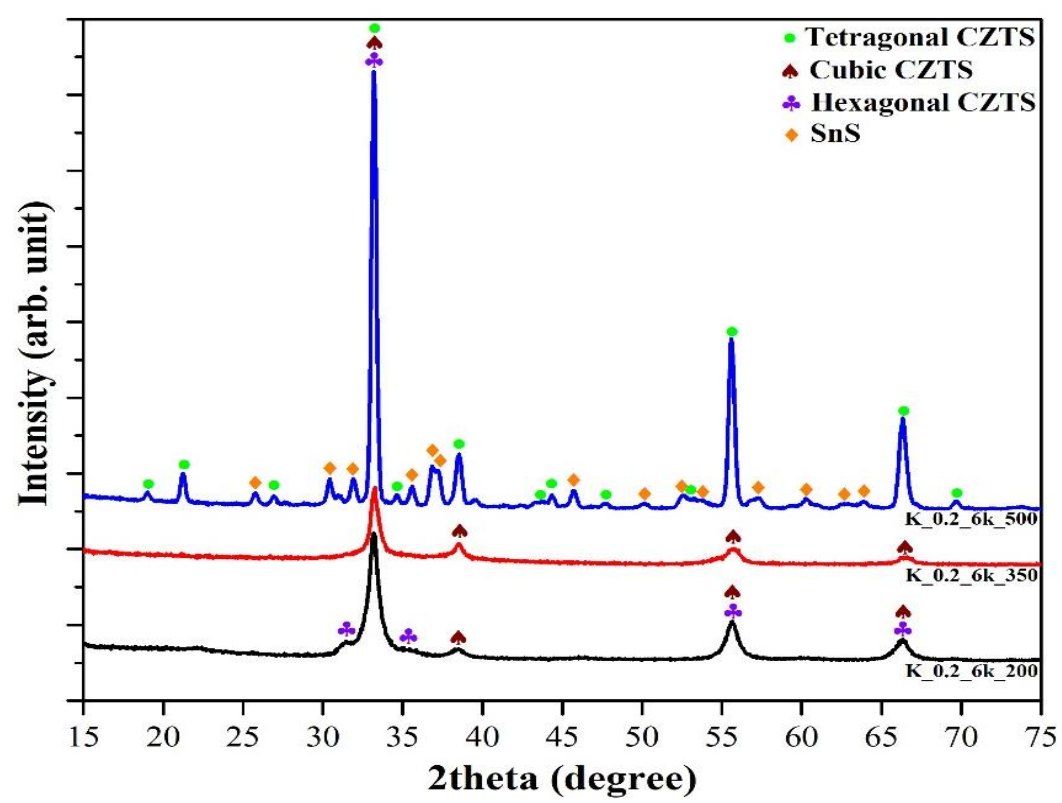

Figure 5. XRD spectra of CZTS thin films treated at $200{ }^{\circ} \mathrm{C}$ (black line), $350{ }^{\circ} \mathrm{C}$ (red line), and $500{ }^{\circ} \mathrm{C}$ (blue line). Identified phases are indicated by corresponding symbols.

The Williamson-Hall (W-H) analysis $[43,44]$ was performed on XRD data to study the effect of the TT temperature on the size of the nanocrystals and on the microstrain. The latter was due to the surface of the nanocrystals but can also be caused by stoichiometric fluctuations [45]. As shown in Figure 6 , the microstrains at TT $200^{\circ} \mathrm{C}$ and TT $350{ }^{\circ} \mathrm{C}$ are greater than that at TT $500{ }^{\circ} \mathrm{C}$. The reduction of the microstrain is probably related to the consequent increase in the size of the crystals, since OLA, which acts as ligand, is decomposed at TT $500^{\circ} \mathrm{C}$, resulting in further grain growth.

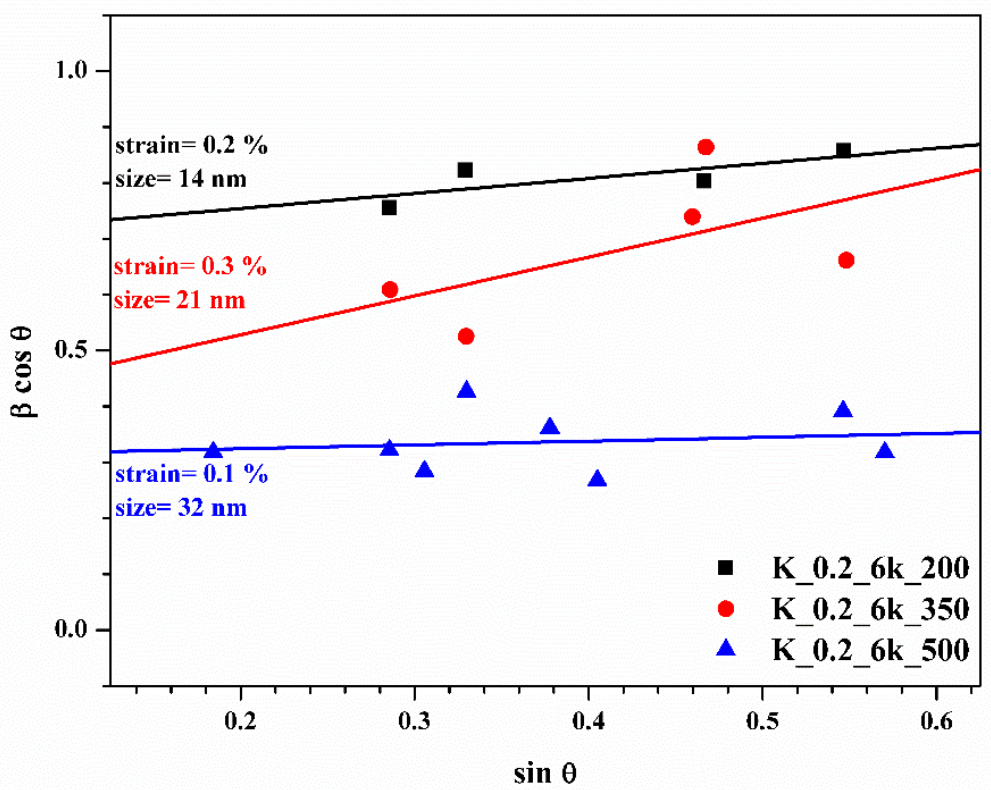

Figure 6. The Williamson-Hall (W-H) analysis ( $\beta$, integral breadth of diffraction peaks; $\theta$, Bragg diffraction angle) of CZTS thin films treated at $200{ }^{\circ} \mathrm{C}$ (black line), $350{ }^{\circ} \mathrm{C}$ (red line), and $500{ }^{\circ} \mathrm{C}$ (blue line).

Figure 7 shows the UV-vis spectroscopy of CZTS thin films deposited on FTO glass under three different TTs. The shift of the transmittance curve towards the visible range for the film treated at $350^{\circ} \mathrm{C}$ 
compared to $200{ }^{\circ} \mathrm{C}$ was due to the absence of a wurtzite phase. As reported [46], films containing wurtzite phase show higher absorptions in the visible range. Furthermore, the transmittance of the film treated at $500{ }^{\circ} \mathrm{C}$ showed a shift toward higher wavelengths due to Sn loss [47]. The maximum peak of transmittance for TT $200{ }^{\circ} \mathrm{C}$ and TT $350{ }^{\circ} \mathrm{C}$ was $\sim 65 \%$; however, it was reduced to $~ 55 \%$ for TT $500{ }^{\circ} \mathrm{C}$. This was due to grain growth, which leads to an increase in surface roughness, causing increased scattering and absorption of light [48].

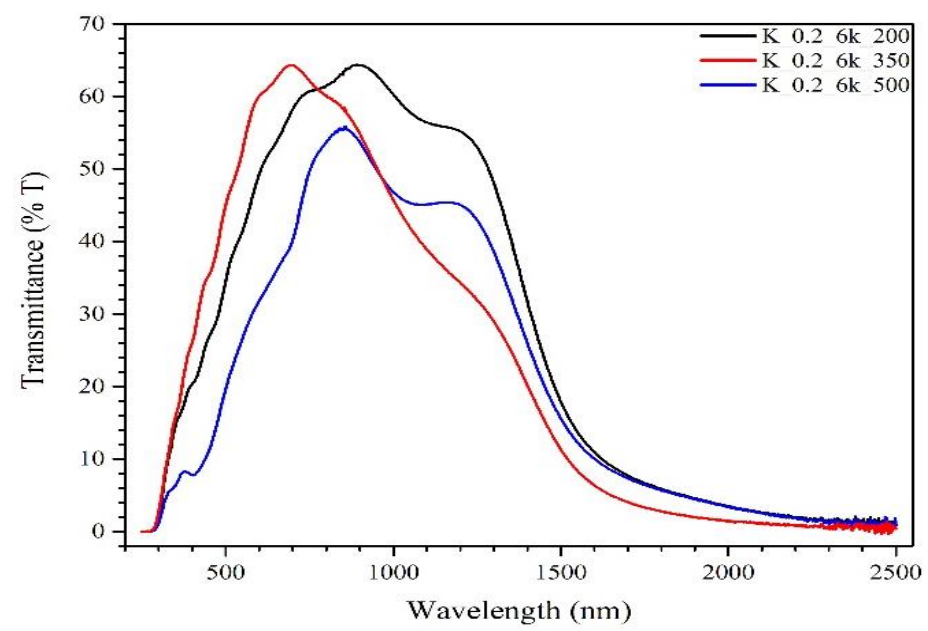

Figure 7. UV-vis spectroscopy of CZTS thin films at different TT temperatures: black line, $200{ }^{\circ} \mathrm{C}$; red line, $350{ }^{\circ} \mathrm{C}$; and blue line, $500{ }^{\circ} \mathrm{C}$.

From the UV-vis spectroscopy data, the band gaps of the thin films were determined to be at $\sim 1.62 \mathrm{eV}$ for TT $200{ }^{\circ} \mathrm{C}, \sim 1.57 \mathrm{eV}$ for TT $350{ }^{\circ} \mathrm{C}$, and $\sim 1.73 \mathrm{eV}$ for TT $500{ }^{\circ} \mathrm{C}$, respectively, which is in good agreement with those reported in the CZTS literature [3,5,6]. However, the slight differences observed among the samples might be due to the different phases present in each sample. In fact, samples at TT $200{ }^{\circ} \mathrm{C}$ and TT $350{ }^{\circ} \mathrm{C}$ showed a similar band gap because a cubic CZTS phase was prevalent in both, although the wurtzite in the TT $200{ }^{\circ} \mathrm{C}$ sample favored a shift of the band gap towards a higher value [49]. The presence of multiple and spurious phases favors the increase of the optical absorption edge towards higher energy values [50] and is confirmed by the high band gap value of the sample treated at $500{ }^{\circ} \mathrm{C}$.

Electrical properties of CZTS thin films were studied at different TT temperatures (TT $200{ }^{\circ} \mathrm{C}$, $350{ }^{\circ} \mathrm{C}$, and $500^{\circ} \mathrm{C}$ ) by Hall effect measurements. Results shown in Table 1 refer to CZTS thin films deposited on soda-lime glass (SLG) as FTO interfered with the measurement of such thin layers. The value of resistivity decreases significantly as the TT temperature increases to $500{ }^{\circ} \mathrm{C}$, which is in agreement with literature [51,52]. Phase changes and microstructures are known to play a role in the electrical properties of CZTS. Resistivity of tetragonal CZTS is lower than other CZTS phases [53], and grain growth and refining are promoted by high-temperature TTs, reducing the amount of defects [21]. However, the large difference observed in resistivity and carrier concentration most probably depends on the presence of organic residuals in the lower temperature TTs [15].

While resistivity and carrier concentration obtained at $500{ }^{\circ} \mathrm{C}$ were better than literature values [54,55], mobility was lower. It has been already observed that carrier mobility is strongly dependent on the microstructure and secondary phase [52], like SnS that formed at $500{ }^{\circ} \mathrm{C}$. Since the carrier mobility is inversely proportional to the resistivity, eliminating the SnS secondary phase will increase carrier mobility, further reducing the resistivity and, thus, improving the overall electrical properties of the CZTS thin film. 
Table 1. Hall effect measurement results of CZTS thin films with different TT temperatures.

\begin{tabular}{ccccc}
\hline Sample & Thickness $(\mathbf{n m})$ & $\begin{array}{c}\text { Resistivity, } \\
\boldsymbol{\rho}(\boldsymbol{\Omega} \cdot \mathbf{c m})\end{array}$ & $\begin{array}{c}\text { Carrier Concentration, } \mathbf{n} \\
\left(\mathbf{c m}^{-3}\right)\end{array}$ & $\begin{array}{c}\text { Carrier Mobility, } \\
\boldsymbol{\mu}\left(\mathbf{c m}^{\mathbf{2}} / \mathbf{V s}\right)\end{array}$ \\
\hline TT $\mathbf{2 0 0}{ }^{\circ} \mathbf{C}$ & $\sim 135$ & $4.0 \times 10^{4}$ & $2 \times 10^{13}$ & 13 \\
TT $\mathbf{3 5 0}{ }^{\circ} \mathrm{C}$ & $\sim 100$ & $4.6 \times 10^{4}$ & $5 \times 10^{12}$ & 27 \\
TT $\mathbf{5 0 0}{ }^{\circ} \mathrm{C}$ & $\sim 90$ & $4.1 \times 10^{-1}$ & $1 \times 10^{21}$ & 0.5 \\
\hline
\end{tabular}

The better electrical properties of the film made at $500{ }^{\circ} \mathrm{C}$ was also demonstrated by cyclic voltammetry $(\mathrm{CV})$ measurements. The cathodic current density $\left(\mathrm{J}_{\mathrm{pc}}\right)$ was determined by the difference between the maximum peak current density and the baseline of charging current density [56]. It is worth noting that the peak at the negative potential corresponds to the reaction $\mathrm{I}_{3}{ }^{-}+2 \mathrm{e}^{-} \rightarrow 3 \mathrm{I}^{-}$, where the current density can be related to the rate of reduction of $\mathrm{I}_{3}{ }^{-}$to $\mathrm{I}^{-}$, occurring at the CZTS electrode. As shown in Figure 8, TT $500{ }^{\circ} \mathrm{C}$ had the highest current density, which can be explained by a better electrocatalytic ability of the electrode [57]. In general, CV confirmed the Hall effect results, demonstrating the importance of high-temperature TTs to make CZTS thin films with better electrical properties. The question that still remains is how to avoid formation of secondary phases, which are detrimental to the mobility of the carriers.

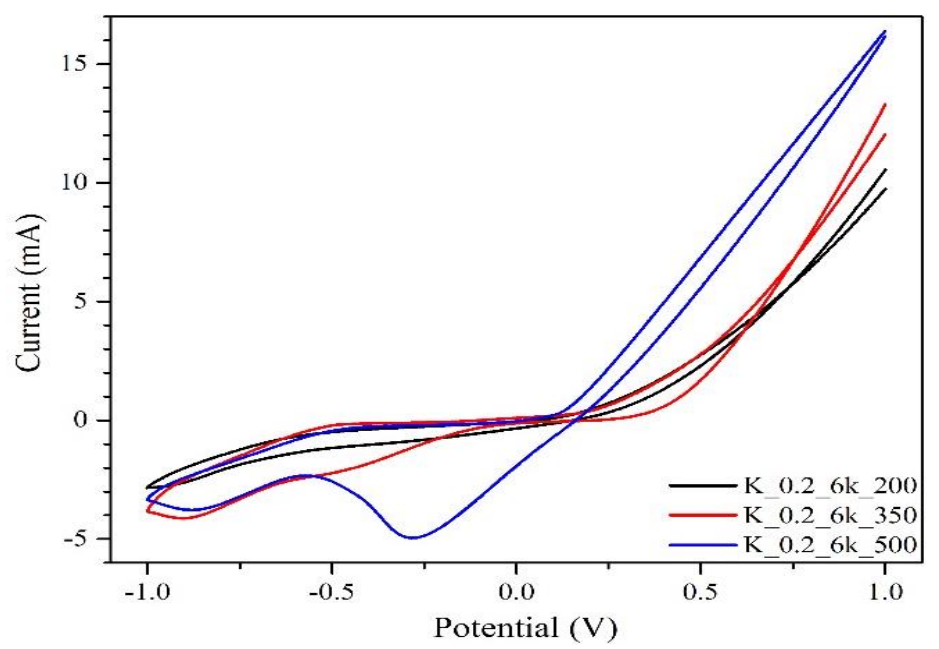

Figure 8. CV of CZTS thin films with different TT temperatures: black line, $200{ }^{\circ} \mathrm{C}$; red line, $350{ }^{\circ} \mathrm{C}$; and blue line, $500{ }^{\circ} \mathrm{C}$.

\section{Materials and Methods}

Copper (II) chloride dihydrate $\left(\mathrm{CuCl}_{2} \cdot 2 \mathrm{H}_{2} \mathrm{O},>99.0 \%\right)$, zinc chloride $\left(\mathrm{ZnCl}_{2},>98.0 \%\right)$, and tin (II) chloride $\left(\mathrm{SnCl}_{2}, 98 \%\right)$ were purchased by Sigma-Aldrich Inc. and dehydrated in vacuum at $200{ }^{\circ} \mathrm{C}$. Sulfur (S), oleylamine (OLA, $\left.70 \%\right)$, toluene $(99.9 \%)$, and ethanol (>99\%) were also provided by Sigma-Aldrich Inc. and used without further purification.

\subsection{Synthesis of CZTS Nanoparticles Ink}

CZTS nanoparticles ink was prepared according to the method described by Ataollahi et al. [15]: $0.538 \mathrm{~g}$ of $\mathrm{CuCl}_{2} \cdot 2 \mathrm{H}_{2} \mathrm{O}, 0.414 \mathrm{~g}$ of $\mathrm{ZnCl}_{2}$, and $0.410 \mathrm{~g}$ of $\mathrm{SnCl}_{2}$ were mixed into a $100 \mathrm{~mL}$ three-neck round-bottom flask containing $6.6 \mathrm{~mL}$ of OLA. The system was connected to a Schlenk line apparatus to carry out the whole process in standard, air-free conditions. OLA was added to work both as a solvent and as a capping agent for the nanoparticles. The mixture was heated first to $130{ }^{\circ} \mathrm{C}$, and at this temperature the flask was degassed and refilled with nitrogen several times and then kept under vacuum. About $8 \mathrm{~mL}$ of a sulfur/OLA $1 \mathrm{M}$ solution (prepared by dissolving $0.449 \mathrm{~g} \mathrm{~S}$ in $10 \mathrm{~mL}$ OLA) was rapidly injected in the hot solution at $270{ }^{\circ} \mathrm{C}$ under fast stirring and nitrogen 
$\left(\mathrm{N}_{2}\right)$ flux. The mixture was kept at $270{ }^{\circ} \mathrm{C}$ for $30 \mathrm{~min}$ after the injection and then cooled slowly to room temperature. The obtained suspension of nanoparticles was washed with a mixture of $5 \mathrm{~mL}$ toluene and $25 \mathrm{~mL}$ ethanol and centrifuged for $10 \mathrm{~min}$ at $4000 \mathrm{rpm}$ to separate the solvent from the nanoparticles. Finally, the CZTS nanoparticles were extracted, dispersed in toluene, and sonicated to obtain an ink with the desired concentration.

\subsection{Deposition of CZTS Thin Film}

The CZTS nanoparticles ink was deposited on SLG substrates by spin coating. Before deposition, the substrates were cleaned with soap, treated with concentrated potassium hydroxide $(\mathrm{KOH}) \mathrm{in}$ ethanol, rinsed with distilled water and ethanol, then dried in $\mathrm{N}_{2}$ stream. The cleaning process of the FTO glass was similar, except for the treatment with $\mathrm{KOH}$, where $20 \mu \mathrm{L}$ of ink was dropped on the substrate. After spin coating, the residual toluene was removed at $150{ }^{\circ} \mathrm{C}$ for $15 \mathrm{~min}$. The TT below $350{ }^{\circ} \mathrm{C}$ was carried out on a hot-plate under $\mathrm{N}_{2}$ atmosphere for $15 \mathrm{~min}$. High-temperature $\mathrm{TT}\left(500{ }^{\circ} \mathrm{C}\right)$ was performed in a tubular furnace at a heating rate of $3^{\circ} \mathrm{C} / \mathrm{min}$ for $1 \mathrm{~h}$ under $\mathrm{N}_{2}$ atmosphere. Samples were labelled according to ink concentration $(0.2$ and $0.5 \mathrm{~g} / \mathrm{mL})$, spin rate (2000-6000 rpm), and TT temperature $\left(150-500^{\circ} \mathrm{C}\right)$.

\subsection{CZTS Thin Film Characterization}

The morphology of CZTS thin film samples was observed either by optical microscopy or by scanning electron microscopy (SEM). Optical microscopy was made on a REMET HX-1000 (Remet, Bologna, Italy) at 400× magnification, whereas for SEM we used a JEOL JSM-7001F FEG-SEM (JEOL, Tokyo, Japan) equipped with an energy-dispersive X-ray spectroscopy detector (EDXS, Oxford INCA PentaFETx3, Oxford, United Kingdom). Observations were made at 10.00-15.00 keV electron beam energy with a working distance between 5-10 mm. Surface morphology images were acquired in top-down modes, whereas a cross-sectional analysis was performed by putting the cross-section of the film on a $90^{\circ}$ stub.

UV-vis spectroscopy of CZTS thin films was made using a Perkin-Elmer LAMBDA 950 spectrophotometer (Perkin-Elmer, Milano, Italy) equipped with a $150 \mathrm{~mm}$ integrating sphere. By measuring normal incidence transmittance and reflectance, the absorption coefficient was calculated using the equation

$$
\alpha=-\frac{1}{d} \ln \left(\frac{T}{1-R}\right)
$$

where:

$\alpha=$ absorption coefficient,

$d=$ film thickness,

$=$ normal incidence transmittance, and

$=$ normal incidence reflectance.

From UV-vis spectroscopy data, the bandgap energy was also obtained by a linear fit of a Tauc plot. Structural information on CZTS thin films were obtained by X-ray diffraction (XRD), using a Panalytical X'Pert MRD instrument equipped with $\mathrm{CoK} \alpha$ sealed tube operated at $40 \mathrm{kV}$ and $40 \mathrm{~mA}$. Phase identification was supported by JADE Software (Materials Data, Inc., Livermore, CA, USA).

Hall effect measurements were made using an electrical testing platform (RH 2030 - PhysTech, Germany) with a current source range of $10^{-10}-10^{-2} \mathrm{~A}$, with maximum resolution of $2.5 \times 10^{-12} \mathrm{~A}$. The maximum output voltage was $\pm 20 \mathrm{~V}$ with the output resistance using a typical $10^{13} \Omega$ resistor. Besides that, the voltage measurement range was $10^{-6}-10^{1} \mathrm{~V}$, with maximum resolution of $3 \times 10^{-7} \mathrm{~V}$. The instrument had a sensitivity of $<1 \mathrm{mV}$ and an input resistance of $>10^{15} \Omega$. The magnetic field was provided by a standard magnet with magnetic field (B) range of 0.05-0.8 $\mathrm{T}$ and an achievable maximum 
resolution of $0.001 \mathrm{~T}$. The pole diameter and gap were 45 and $0-75 \mathrm{~mm}$, respectively. The resistivity value was calculated by using the formula

$$
\rho=\frac{1}{\sigma}=\frac{1}{q \mu n}
$$

where:

$\rho=$ sample resistivity $(\Omega \cdot \mathrm{cm})$,

$\sigma=$ sample conductivity $\left(\Omega^{-1} \cdot \mathrm{cm}^{-1}\right)$,

$=$ charge constant $\left(1.6 \times 10^{-19} \mathrm{C}\right)$,

$\mu=$ carrier mobility $\left(\mathrm{cm}^{2} / \mathrm{Vs}\right)$, and

$=$ carrier concentration $\left(\mathrm{cm}^{-3}\right)$.

Cyclic voltammetry (CV) was conducted on Princeton Applied Research (PAR) model no. 4000 A with a three-electrodes system. Silver/silver chloride $(\mathrm{Ag} / \mathrm{AgCl})$ was the reference electrode, platinum $(\mathrm{Pt})$ was the counter electrode, and CZTS thin film samples were deposited on the FTO glass as working electrodes with iodide/triiodide ion $\left(\mathrm{I}^{-} / \mathrm{I}_{3}{ }^{-}\right)$electrolytes using a methanol solution containing $0.5 \mathrm{M}$ potassium iodide (KI) and $0.5 \mathrm{mM} \mathrm{I}_{2}$. Scanning was done at a rate of $50 \mathrm{mV} \mathrm{s}^{-1}$.

\section{Conclusions}

Ink containing CZTS nanoparticles was successfully synthesized by the hot-injection method using metal chloride precursors, sulfur, and OLA. It was found that the ink concentration affected the thickness and surface morphology of the deposited film. The spin rate can be manipulated to obtain films with different thicknesses. Both a lower ink concentration and a higher spin rate produced CZTS thin films with lower thickness, higher transmittance, and better morphology. Moreover, the different thermal treatment temperatures (from 150 to $500^{\circ} \mathrm{C}$ ) affect more than other parameters on the overall quality, surface morphology, crystal structure, transmittance behavior, band gap energy, and electrical properties of the CZTS thin film. The increase in TT temperature induces significant phase changes (wurtzite CZTS $\rightarrow$ cubic CZTS $\rightarrow$ tetragonal CZTS) in addition to an improvement in the crystallinity degree and electrical properties. While high-temperature TTs are required to get rid of organic residuals and increase conductivity and carrier concentration, they can also lead to formation of secondary phases like SnS, which is detrimental to the mobility of the carriers. A correct balance between different requirements in thin film production still has yet to be found. The method is confirmed to be very versatile for preparing CZTS sub-micrometric thin films $(<0.5 \mu \mathrm{m})$ and semiconductors suitable for a transport layer in many applications such as in solar cells, diodes, and thermoelectric devices.

Author Contributions: Conceptualization, P.S., N.A. and U.S.; methodology, U.S., N.A., and R.D.M.; experimental investigation, U.S. and N.A; resources, P.S. and R.D.M.; data curation and interpretation, U.S. and N.A; writing-original draft preparation, U.S.; writing-review and editing, N.A., P.S., and R.D.M.; supervision, P.S. and N.A; funding acquisition, P.S.

Funding: This research was funded by the Autonomous Province of Trento for the support provided within the framework of the programmatic Energy Action 2015-2017.

Acknowledgments: The authors thank Nicola Bazzanella for the SEM measurements, Puvaneswaran Chelvanathan for the Hall effect measurement, and Mirco D'Incau for the helpful comments and suggestions.

Conflicts of Interest: The authors declare no conflicts of interest. The funders had no role in the design of the study; in the collection, analyses, or interpretation of data; in the writing of the manuscript, or in the decision to publish the results. 


\section{References}

1. Nakayama, N.; Ito, K. Sprayed films of stannite Cu2ZnSnS4. Appl. Surf. Sci. 1996, 92, 171-175. [CrossRef]

2. Kattan, N.; Hou, B.; Fermín, D.J.; Cherns, D. Crystal structure and defects visualization of Cu2ZnSnS4 nanoparticles employing transmission electron microscopy and electron diffraction. Appl. Mater. Today 2015, 1, 52-59. [CrossRef]

3. Gonce, M.K.; Dogru, M.; Aslan, E.; Ozel, F.; Patir, I.H.; Kus, M.; Ersoz, M. Photocatalytic Hydrogen Evolution Based on Cu2ZnSnS4, Cu2ZnSnSe4, Cu2ZnSnSe4-xSx Nanofibers. RSC Adv. 2015, 5, 94025-94028. [CrossRef]

4. Ricardo, C.L.A.; Girardi, F.; Cappelletto, E.; D'Angelo, R.; Ciancio, R.; Carlino, E.; Ricci, P.C.; Malerba, C.; Mittiga, A.; Di Maggio, R.; et al. Chloride-based route for monodisperse Cu2ZnSnS4 nanoparticles preparation Chloride-based route for monodisperse $\mathrm{Cu} 2 \mathrm{ZnSnS} 4$ nanoparticles preparation. J. Renew. Sustain. Energy 2015, 7 .

5. Huang, S.; Luo, W.; Zou, Z. Band positions and photoelectrochemical properties of $\mathrm{Cu}_{2} \mathrm{ZnSnS}_{4}$ thin films by the ultrasonic spray pyrolysis method. J. Phys. D. Appl. Phys. 2013, 46, 235108. [CrossRef]

6. Murata, M.; Chantana, J.; Ashida, N.; Hironiwa, D.; Minemoto, T. Influence of conduction band minimum difference between transparent conductive oxide and absorber on photovoltaic performance of thin-film solar cell In $\mathrm{fl}$ uence of conduction band minimum difference between transparent conductive oxide and absorber on ph. Jpn. J. Appl. Phys. 2015, 54, 032301. [CrossRef]

7. Park, S.-N.; Sung, S.-J.; Sim, J.-H.; Yang, K.-J.; Hwang, D.-K.; Kim, J.; Kim, G.Y.; Jo, W.; Kim, D.-H.; Kang, J.-K. Nanostructured p-type CZTS thin films prepared by facile solution process for 3D p-n junction solar cells. Nanoscale 2015, 7, 11182-11189. [CrossRef]

8. Habas, S.E.; Platt, H.A.S.; van Hest, M.F.A.M.; Ginley, D.S. Low-Cost Inorganic Solar Cells: From Ink To Printed Device. Chem. Rev. 2010, 110, 6571-6594. [CrossRef]

9. Abermann, S. Non-vacuum processed next generation thin film photovoltaics: Towards marketable efficiency and production of CZTS based solar cells. Sol. Energy 2013, 94, 37-70. [CrossRef]

10. Jiang, M.; Yan, X. Cu2ZnSnS4 thin film solar cells: present status and future prospects. Sol. Cells Res. Appl. Perspect. 2013, 107-143. [CrossRef]

11. Yin, Y.; Alivisatos, A.P. Colloidal nanocrystal synthesis and the organic-inorganic interface. Nature 2005, 437, 664-670. [CrossRef]

12. Ananthakumar, S.; Kumar, R. Influence of co-ordinating and non-coordinating solvents in structural and morphological properties of Cu2ZnSnS4 (CZTS) nanoparticles. Optik (Stuttg). 2017, 130, 99-105.

13. Huang, T.J.; Yin, X.; Tang, C.; Qi, G.; Gong, H. Influence of Ligands on the Formation of Kesterite Thin Films for Solar Cells: A Comparative Study. 2016, 9, 1032-1041. [CrossRef]

14. Zhang, X.; Guo, G.; Ji, C.; Huang, K.; Zha, C.; Wang, Y.; Shen, L.; Gupta, A.; Bao, N. Efficient Thermolysis Route to Monodisperse Cu2ZnSnS4 Nanocrystals with Controlled Shape and Structure. Sci. Rep. 2015, 4, 5086. [CrossRef]

15. Ataollahi, N.; Malerba, C.; Cappelletto, E.; Ciancio, R.; Edla, R.; Di Maggio, R.; Scardi, P. Control of composition and grain growth in $\mathrm{Cu} 2 \mathrm{ZnSnS} 4$ thin films from nanoparticle inks. Thin Solid Films 2019, 674, 12-21. [CrossRef]

16. Hadke, S.H.; Levcenko, S.; Lie, S.; Hages, C.J.; Márquez, J.A.; Unold, T.; Wong, L.H. Synergistic Effects of Double Cation Substitution in Solution-Processed CZTS Solar Cells with over 10\% Efficiency. Adv. Energy Mater. 2018, 8, 1-9. [CrossRef]

17. Datta, S.K.; Chaudhuri, A.K. On the mechanism of photoconductivity in polycrystalline lead selenide films. Semicond. Sci. Technol. 1989, 4, 376-381. [CrossRef]

18. Pal, U. Dark- and photoconductivity in doped and undoped zinc telluride films. Semicond. Sci. Technol. 1993, 8, 1331-1336. [CrossRef]

19. Pal, R.; Chattopadhyay, K.K.; Chaudhuri, S.; Pal, A.K. Photoconductivity in CuInSe2 films. Sol. Energy Mater. Sol. Cells 1994, 33, 241-251. [CrossRef]

20. Kosyak, V.; Karmarkar, M.A.; Scarpulla, M.A. Temperature dependent conductivity of polycrystalline Cu2ZnSnS4 thin films. Appl. Phys. Lett. 2012, 100, 263903. [CrossRef]

21. Ghediya, P.R.; Chaudhuri, T.K.; Vankhade, D. Electrical conduction of CZTS films in dark and under light from molecular solution ink. J. Alloys Compd. 2016, 685, 498-506. [CrossRef] 
22. González, J.C.; Ribeiro, G.M.; Viana, E.R.; Fernandes, P.A.; Salomé, P.M.P.; Gutiérrez, K.; Abelenda, A.; Matinaga, F.M.; Leitão, J.P.; da Cunha, A.F. Hopping conduction and persistent photoconductivity in Cu2ZnSnS4 thin films. J. Phys. D. Appl. Phys. 2013, 46, 155107. [CrossRef]

23. Moholkar, A.V.; Shinde, S.S.; Babar, A.R.; Sim, K.U.; bin Kwon, Y.; Rajpure, K.Y.; Patil, P.S.; Bhosale, C.H.; Kim, J.H. Development of CZTS thin films solar cells by pulsed laser deposition: Influence of pulse repetition rate. Sol. Energy 2011, 85, 1354-1363. [CrossRef]

24. Park, H.; Hwang, Y.H.; Bae, B.S. Sol-gel processed Cu2ZnSnS4 thin films for a photovoltaic absorber layer without sulfurization. J. Sol-Gel Sci. Technol. 2013, 65, 23-27. [CrossRef]

25. Muslih, E.Y.; Kim, K.H. Characteristics of Cu2ZnSnS4 thin film prepared by calcination and sulfurizing of metal $(\mathrm{Cu}, \mathrm{Zn}, \mathrm{Sn})$-ethanolamine precursor complexed from metal $(\mathrm{Cu}, \mathrm{Zn}, \mathrm{Sn})$-hydrate. Chalcogenide Lett. 2015, 12, 349-355.

26. Tao, J.; Chen, L.; Cao, H.; Zhang, C.; Liu, J.; Zhang, Y.; Huang, L.; Jiang, J.; Yang, P.; Chu, J. Co-electrodeposited Cu2ZnSnS4 thin-film solar cells with over 7\% efficiency fabricated via fine-tuning of the Zn content in absorber layers. J. Mater. Chem. A 2016, 4, 3798-3805. [CrossRef]

27. Khanzada, L.S.; Levchuk, I.; Hou, Y.; Azimi, H.; Osvet, A.; Ahmad, R.; Brandl, M.; Herre, P.; Distaso, M.; Hock, R.; et al. Effective Ligand Engineering of the Cu2ZnSnS4 Nanocrystal Surface for Increasing Hole Transport Efficiency in Perovskite Solar Cells. Adv. Funct. Mater. 2016, 26, 8300-8306. [CrossRef]

28. Zuo, Y.; Chen, L.; Jiang, W.; Liu, B.; Zeng, C.; Li, M.; Shi, X. High-efficiency perovskite solar cells improved with low-cost orthorhombic Cu 2 Znsns 4 as the hole-transporting layer. Mater. Tehnol. 2018, 52, 483-486. [CrossRef]

29. Wu, Q.; Xue, C.; Li, Y.; Zhou, P.; Liu, W.; Zhu, J.; Dai, S.; Zhu, C.-F.; Yang, S. Kesterite Cu2ZnSnS4 as a Low Cost Inorganic Hole Transporting Material for High Efficiency Perovskite Solar Cells. ACS Appl. Mater. Interfaces 2015, 7, 28466-28473. [CrossRef]

30. Deganello, D. Printing Techniques for the Fabrication of OLEDs; Woodhead Publishing Limited: Sawston/Cambridge, UK, 2013; ISBN 9780857094254.

31. Tsuda, A.; Venkata, N.K. The role of natural processes and surface energy of inhaled engineered nanoparticles on aggregation and corona formation. NanoImpact 2016, 2, 38-44. [CrossRef]

32. Prasad, P.S.R.K.; Reddy, A.V.; Rajesh, P.K.; Ponnambalam, P.; Prakasan, K. Studies on rheology of ceramic inks and spread of ink droplets for direct ceramic ink jet printing. J. Mater. Process. Technol. 2006, 176, 222-229. [CrossRef]

33. Soares, J.A.N.T. Introduction to Optical Characterization of Materials. In Practical Materials Characterization; Sardela, M., Ed.; Springer: New York, NY, USA, 2014; pp. 43-92. ISBN 9781461492818.

34. Ingle, J.D.J.; Crouch, S.R. Spectrochemical analysis; Prentice Hall: Upper Saddle River, NJ, USA, 1988.

35. Akaltun, Y.; Yildirim, M.A.; Ateş, A.; Yildirim, M. The relationship between refractive index-energy gap and the film thickness effect on the characteristic parameters of CdSe thin films. Opt. Commun. 2011, 284, 2307-2311. [CrossRef]

36. Li, W.; Tan, J.M.R.; Leow, S.W.; Lie, S.; Magdassi, S.; Wong, L.H. Recent Progress in Solution-Processed Copper-Chalcogenide Thin-Film Solar Cells. Energy Technol. 2018, 6, 46-59. [CrossRef]

37. Yu, N.; Zhong, R.; Zhong, W.; Chen, X.; Luo, J.; Gu, X.; Hu, X.; Zhang, L.; Hu, J.; Chen, Z. Synthesis of Cu2ZnSnS4film by air-stable molecular-precursor ink for constructing thin film solar cells. RSC Adv. 2014, 4, 36046-36052. [CrossRef]

38. Kim, H.T.; Kim, D.; Park, C. Temperature effects on Cu 2ZnSnS 4 (CZTS) films deposited by spraying method. Mol. Cryst. Liq. Cryst. 2012, 564, 155-161. [CrossRef]

39. Singh, S.; Brandon, M.; Liu, P.; Laffir, F.; Redington, W.; Ryan, K.M. Selective Phase Transformation of Wurtzite Cu2ZnSn ( SSe ) 4 Nanocrystals into Zinc Blende and Kesterite by Solution and Solid State Transformations Selective Phase Transformation of Wurtzite Cu 2 ZnSn ( SSe ) 4 Nano- crystals into Zinc Blende and Kesteri. Chem. Mater. 2016, 28, 5055-5062. [CrossRef]

40. Isotta, E.; Pugno, N.M.; Scardi, P. Nanostructured kesterite (Cu2ZnSnS4) for applications in thermoelectric devices. Powder Diffr. 2019, 1-6. [CrossRef]

41. Kapusta, K.; Drygas, M.; Janik, J.F.; Jelen, P.; Bucko, M.M.; Olejniczak, Z. From magnetic cubic pre-kesterite to semiconducting tetragonal kesterite $\mathrm{Cu} 2 \mathrm{ZnSnS4}$ nanopowders via the mechanochemically assisted route. J. Alloys Compd. 2019, 770, 981-988. [CrossRef] 
42. Indubala, E.; Sarveshvaran, S.; Sudha, V.; Mamajiwala, A.Y.; Harinipriya, S. Secondary phases and temperature effect on the synthesis and sulfurization of CZTS. Sol. Energy 2018, 173, 215-224. [CrossRef]

43. Williamson, G.; Hall, W. X-ray line broadening from filed aluminium and wolfram. Acta Metall. 1953, 1, 22-31. [CrossRef]

44. Scardi, P.; Leoni, M.; Delhez, R. IUCr Line broadening analysis using integral breadth methods: A critical review. J. Appl. Crystallogr. 2004, 37, 381-390. [CrossRef]

45. Scardi, P. Chapter 13. Microstructural Properties: Lattice Defects and Domain Size Effects. In Powder Diffraction; Royal Society of Chemistry: Cambridge, 2008; pp. 376-413.

46. Ahmad, R.; Brandl, M.; Distaso, M.; Herre, P.; Spiecker, E.; Hock, R.; Peukert, W. A comprehensive study on the mechanism behind formation and depletion of Cu2ZnSnS4 (CZTS) phases. CrystEngComm 2015, 17, 6972-6984. [CrossRef]

47. Malerba, C.; Biccari, F.; Leonor, C.; Ricardo, A.; Valentini, M.; Chierchia, R.; Müller, M.; Santoni, A.; Esposito, E.; Mangiapane, P.; et al. CZTS stoichiometry effects on the band gap energy. J. Alloys Compd. 2014, 582, 528-534. [CrossRef]

48. Zhang, S.; Wang, T.; Lin, S.; Zhang, Y.; Tesfamichael, T.; Bell, J.; Wang, H. Effect of different thermo-treatment at relatively low temperatures on the properties of indium-tin-oxide thin films. Thin Solid Films 2017, 636, 702-709. [CrossRef]

49. Safdar, A.; Islam, M.; Akram, M.A.; Mujahid, M.; Khalid, Y.; Shah, S.I. Reaction Time and Film Thickness Effects on Phase Formation and Optical Properties of Solution Processed Cu2ZnSnS4 Thin Films. J. Mater. Eng. Perform. 2016, 25, 457-465. [CrossRef]

50. Ghorpadea, U.V.; Suryawanshi, M.P.; Shin, S.W.; woo Hong, C.; Kim, I.; Moon, J.H.; Yun, J.H.; Kima, J.H.; Kolekar, S.S. Wurtzite CZTS Nanocrystals and Phase Evolution to Kesterite Thin Film for Solar Energy Harvesting. Phys. Chem. Chem. Phys. 2015, 17, 19777-19788. [CrossRef]

51. Swami, S.K.; Kumar, A.; Dutta, V. Deposition of kesterite Cu 2 ZnSnS 4 (CZTS) thin films by spin coating technique for solar cell application. Energy Procedia 2013, 33, 198-202. [CrossRef]

52. Shin, S.W.; Pawar, S.M.; Park, C.Y.; Yun, J.H.; Moon, J.-H.; Kim, J.H.; Lee, J.Y. Studies on Cu2ZnSnS4 (CZTS) absorber layer using different stacking orders in precursor thin films. Sol. Energy Mater. Sol. Cells 2011, 95, 3202-3206. [CrossRef]

53. Al-Shakban, M.; Matthews, P.D.; Savjani, N.; Zhong, X.L.; Wang, Y.; Missous, M.; O’Brien, P. The synthesis and characterization of $\mathrm{Cu} 2 \mathrm{ZnSnS} 4$ thin films from melt reactions using xanthate precursors. J. Mater. Sci. 2017, 52, 12761-12771. [CrossRef]

54. Muhunthan, N.; Singh, O.P.; Singh, S.; Singh, V.N. Growth of CZTS thin films by co-sputtering of metal targets and sulfurization in H 2 S N. Muhunthan, Om Pal Singh, Son Singh, and V.N. Singh* CSIR-National Physical Laboratory, Dr. K. S. Krishnan Marg, New Delhi-110012. Int. J. Photoenergy 2013, 2013, 1-23. [CrossRef]

55. Islam, M.A.; Aziz, A.; Witjaksono, G.; Amin, N. Structural, Electrical and Optical Properties of Zn Rich CZTS Thin Film. IEEE Student Conf. Res. Dev. 2013, 16-17.

56. Bard, A.J.; Faulkner, L.R. Electrochemical Methods: Fundamentals and Applications; Wiley: Hoboken, NJ, USA, 2001; ISBN 9780471043720.

57. Yue, G.; Ma, X.; Zhang, W.; Li, F.; Wu, J.; Li, G. A highly efficient flexible dye-sensitized solar cell based on nickel sulfide/platinum/titanium counter electrode. Nanoscale Res. Lett. 2015, 10, 1. [CrossRef]

Sample Availability: Not available. 